\title{
PERAN KEPOLISIAN, BNNP DAN MASYARAKAT DALAM PENANGGULANGAN NARKOTIKA DI ACEH TIMUR
}

\section{THE ROLE OF THE POLICE, BNNP AND SOCIETY IN MANAGING NARCOTICS IN EAST ACEH}

\author{
Mukhsalmina $^{1}$, Mukhlis $^{2}$, Yusrizal $^{3}$ \\ 1. Mahasiswa Prodi Magister Ilmu Hukum Universitas \\ 2. Dosen Fakultas Hukum Universitas Malikussaleh \\ 3. Dosen Fakultas Hukum Universitas Malikussaleh \\ Email: mukhlis.dr@unimal.ac.id
}

\begin{abstract}
The practice of drug abuse and trafficking in East Aceh is very worrying. Methamphetamine cases in 2018 totaled 119 cases, 75 cases in 2019 and 45 cases in 2020. The study aims to analyze the role of the Police, (BNNP) and the community in tackling and coordinating narcotics crime prevention in East Aceh. The author uses empirical juridical research methods. The legal materials used are primary legal materials, secondary legal materials and tertiary legal materials. Data analysis was carried out qualitatively. The results of the study indicate that the police, BNNP and the community have a strategic role in tackling narcotics practices and coordination is less effective because the position of BNNP does not yet exist in East Aceh.
\end{abstract}

\section{Intisari}

Praktik penyalahgunaan dan peredaran narkotika di Aceh Timur sangat mengkhawatirkan. Kasus sabu tahun 2018 berjumlah 119 kasus, 75 kasus tahun 2019 dan 45 kasus tahun 2020. Penelitian bertujuan menganalisis peran Kepolisian, (BNNP) dan masyarakat dalam menanggulangi dan koordinasi dalam penanggulangan kejahatan narkotika di Aceh Timur. Penulis menggunakan metode penelitian yuridis empiris. Bahan hukum yang digunakan adalah bahan hukum primer, bahan hukum sekunder dan bahan hukum tertier. Analisis data dilakukan secara kualitatif. Hasil penelitian menunjukkan bahwa kepolisian, BNNP dan masyarakat memiliki peran strategis dalam menanggulangi praktik narkotika dan koordinasi kurang berjalan efektif karena kedudukan BNNP belum ada di Aceh Timur.

Kata Kunci: Narkotika, Kejahatan, Pidana. 


\section{A. Latar Belakang Masalah}

Persoalan penyalahgunaan narkotika selalu menjadi isu yang sangat menarik didiskuskan dalam berbagai kesempatan. Pemberitaan penangkapan pelaku penyalahgunaan narkotika yang dilakukan oleh Kepolisian Resor Aceh Timur menunjukkan bahwa praktik penyalahgunaan narkotika terus berkembang. Ada dalam kuantitas yang banyak dan ada pula penangkapan dengan kuantitas yang sedang dan ada pula dengan jumlah yang relatif kecil. Pada bulan April tahun 2020 Kepolisian Resor Aceh menangkap lima orang nelayan dilengkapi dengan barang bukti sabu yang berjumlah $45 \mathrm{Kg} .{ }^{1}$ Kemudian pada bulan Februari 2020 Badan Narkotika Langsa menangkap bandar sabu di Kabupaten Aceh Timur sekaligus menyita $18 \mathrm{Kg}$ barang bukti. $^{2}$ Pada bulan yang sama polisi menangkap tiga orang penyalahgunaan narkotika dengan barang bukti 42 bungkus Koran. ${ }^{3}$ Menurut Gunawan, penyalahgunaan dan Peredaran gelap narkotika merupakan suatu isu yang sangat sentral dan krusial serta dapat menjadi ancaman yang serius bagi suatu negara. ${ }^{4}$ Di samping itu, praktik kejahatan narkotika ini pula memiliki dukungan dana yang besar dan sudah menggunakan fasilitas teknologi yang canggih. ${ }^{5}$

Berdasarkan data yang diperoleh dari Kepolisian Resor Aceh Timur menunjukkan angka kejahatan narkotika yang dilakukan oleh masyarakat sungguh mengkhawirkan. Jumlah data tersebut dapat dilihat pada table berikut ini:

\begin{tabular}{|l|l|l|l|l|}
\hline No & Jenis Narkotika & Tahun & Jumlah Kasus & Jumlah Barang Bukti \\
\hline \multirow{3}{*}{1} & \multirow{3}{*}{ Ganja } & 2018 & 24 kasus & 124.247 .37 gram \\
\cline { 3 - 5 } & & 2019 & 18 kasus & 442.761 .95 gram \\
\cline { 3 - 5 } & 2020 & 7 kasus & 555.46 gram \\
\hline \multirow{3}{*}{2} & \multirow{3}{*}{ Sabu } & 2018 & 119 & 23.123 .64 gram \\
\cline { 3 - 5 } & & 2019 & 75 & 34.998 .59 gram \\
\cline { 3 - 5 } & 2020 & 45 & 45.553 .9 gram \\
\hline
\end{tabular}

Tabel 1: Data diperoleh dari Polres Aceh Timur

Berdasarkan data di atas menunjukkan bahwa angka kasus yang ditangkap oleh kepolisian semakin menurun setiap tahunnya. Akan tetapi dari sisi kuantitas jumlah barang bukti yang ditemukan semakin meningkat setiap tahunnya. Hal ini merupakan suatu fenomena yang perlu mendapatkan perhatian dari berbagai kalangan. Terutama

\footnotetext{
${ }^{1}$ https://aceh.tribunnews.com/2020/04/17/polres-aceh-timur-amankan-sabu-sekitar-45-kgtermasuk-lima-tersangka-nelayan, diakses pada hari Senin, 19 Mei 2020.

${ }^{2}$ https://www.ajnn.net/news/bnn-tangkap-bandar-narkoba-di-aceh-timur-18-kg-sabudisita/index.html, diakses pada hari Senin 19 Mei 2020.

${ }^{3}$ https://aceh.antaranews.com/berita/119321/polisi-ciduk-tiga-pria-penyalahgunaan-narkotika-diaceh-timur, diakses pada hari Senin 19 Mei 2020.

${ }^{4}$ Gunawan Antiprawiro, "Peran Masyarakat Dalam Pencegahan Dan Penanggulangan Terhadap Penyalahgunaan Dan Peredaran Gelap Narkotika", Sociae Polites, vol. 15, No. 2, 2014, hlm $142 .$.

${ }^{5}$ Fransiska Novita Eleanora, Bahaya Penyalahgunaan Narkoba Serta Usaha Pencegahan Dan Penanggulangannya (Suatu Tinjauan Teoritis), Jurnal Hukum, Vol XXV, No. 1, April 2011, hlm. 440.
} 
aparat penegak hukum yakni Kepolisian, Badan Narkotika Nasional Kabupaten dan Provinsi serta masyarakat harus memiliki sinergisitas dalam mengungkapkan praktik kejahatan narkotika. Hal ini sangatlah dibutuhkan agar praktik penyalahgunaan narkotika dikalangan masyarakat dengan baik.

Tindakan pencegahan merupakan salah satu upaya penting dalam pengurangan resiko hasil inovasi bidang narkotika bagi masyarakat. Secara konseptual, pencegahan merupakan suatu upaya untuk menghindarkan terjadinya sesuatu yang tidak dikehendaki. Dari ketentuan hukum yang terkait dengan narkotika yang ada, aktor utama dalam pencegahan penyalahgunaan dan peredaran gelap narkotika, pada prinsipnya terdiri dari 3 kelompok, yakni pemerintah (public sector); lembaga usaha (Privat sector), dan masyarakat (collective action sector). ${ }^{6}$ Pencegahan atau penanggulangan penyalahgunaan narkoba merupakan suatu upaya yang ditempuh dalam rangka penegakan baik terhadap pemakaian, produksi maupun peredaran gelap narkotika yang dapat dilakukan oleh setiap orang baik individu, masyarakat dan negara. ${ }^{7}$ Selain Kepolisian dan BNN, aparatur gampong yang memiliki peranan sangat penting dalam menanggulangi praktik kejahatan narkotika yang terjadi di gampongnya masing-masing.

Berdasarkan permasahan di atas, penelitian ini bertujuan untuk Bagaimanakah peran Kepolisian, Badan Narkotika Nasional Provinsi dan masyarakat dalam penaggulangan kejahatan narkotika di Kabupaten Aceh Timur? Dan Bagaimanakah koordinasi antara Kepolisian, Badan Narkotika Nasional Provinsi dan masyarakat menanggulangi praktik penyalahgunaan narkotika?

\section{B. Metode Penelitian}

Metode penelitian yang digunakan untuk menganalisis persoalan ini penelitian yuridis empiris. Data primer diperoleh melalui wawancara secara mendalam (dept interview) dengan polisi, anggota BNNP dan masyarakat. Bahan hukum sekunder yang digunakana adalah UU Nomor 35 Tahun 2009 dan Undang-Undang Nomor 2 Tahun 2002 dan Peraturan Presiden Republik Indonesia Nomor 23 Tahun 2010. Analisis data dilakukan secara kualitatif.

Berdasarkan permasalahan sebagaimana yang telah penulis deskripsikan dalam latar belakangan masalah di atas, maka penelitian memformulasikan dalam tiga rumusan masalah, yaitu:

1. Bagaimanakah peran Kepolisian, Badan Narkotika Nasional Provinsi dan masyarakat dalam penaggulangan kejahatan narkotika di Kabupaten Aceh Timur?

2. Bagaimanakah koordinasi antara Kepolisian, Badan Narkotika Nasional Provinsi dan masyarakat menanggulangi praktik penyalahgunaan narkotika?

${ }^{6}$ Gunawan Antiprawiro, "Peran Masyarakat Dalam Pencegahan dan Penanggulangan Terhadap Penyalahgunaan Dan Peredaran Gelap Narkotika", Sociae Polites, vol. 15, No. 2, 2014, hlm. 124.

${ }^{7}$ Bayu Puji Hariyanto, Pencegahan dan Pemberantasan Peredaran Narkoba Di Indonesia, Jurnal Daulat Hukum, vol. 1, no. 1, 2018, hlm. 207. 


\section{Hasil Penelitian dan Pembahasan}

\section{Peran Kepolisian, Badan Narkotika Nasional Provinsi dan Masyarakat dalam Penaggulangan Kejahatan narkotika di Kabupaten Aceh Timur}

Narkoba menjadi kejahatan yang luar biasa, bahkan penggunaannya telah dilakukan oleh anak muda yang sebenarnya masih panjang masa depannya. ${ }^{8}$ Kosekuensi logis dari kejahatan yang luar biasa adalah membutuhkan penanggulangan dengan cara-cara yang lebih luar biasa agar keberadaan dan pusat peredarannya dapat diidentifikasi oleh penegak hukum. Ketertlibatan berbagai komponen dalam menggunggapkan kejahatan itu sangat dibutuhkan agar dapat memudahkan. Hadirnya penegak hukum seperti Kepolisian, Badan Narkotika Nasional Provinsi dan masyarakat tentu memiliki peranan yang sangat strategis untuk mengurangi praktik kejahatan narkotika di Aceh Timur.

Menurut Irwansyah, Kepolisian Aceh Timur memiliki peran yang sangat penting dalam hal pencegahan dan penanggulangan peredaran narkotika. Adanya kepolisian yang diberikan tugas untuk menegakkan hukum sehingga dapat mengungkapkan kasus penyalahgunaan narkotika di Aceh Timur secara baik. ${ }^{9}$ Menurut Agus Satria, untuk melaksanakan tugas di bidang penyalahgunaan narkotika membutuhkan kehati-hatian dan kinerja yang sistematis serta tidak dilakukan secara terburu-buru. Jika dilakukan secara tergesa-gesa dapat berakibat fatal dan tidak mampu mengusut secara tuntas kasus penyalahgunaan narkotika. ${ }^{10}$ Selain itu, kinerja tim juga sangat dibutuhkan agar praktik peredaran dan penyalahgunaan narkotika di Aceh Timur dapat diungkapkan ke permkukaan. Bila kinerja tim kurang solid dan dilakukan secara tidak terstruktur maka sulit harapan pemberantasan narkotika dapat berjalan secara lancer sebagaimana yang diharapkan. ${ }^{11}$ Misalnya, bagian inteligen perlu mengatur langkah yang tepat agar gerak-geriknya tidak terdeteksi oleh pelaku, begitu pula tim lainnya perlu terus menerus membangun komunikasi yang aktif agar pelaku yang diincarkan dapat ditemukan. ${ }^{12}$

Menurut Kepala Unit Resort Kriminal Polres Aceh Timur, kepolisian terlibat aktif dalam upaya penanggulangan penyalahgunana narkotika di wilayah Aceh Timur. ${ }^{13}$ Hal ini ditandai dengan banyaknya kasus-kasus yang telah dilakukan penangkapan yang berujung kepada penghukuman bagi para pelakunya. ${ }^{14}$ Penanggulangan kejahatan narkotika sebagai bagian dari penyakit masyarakat menjadi bagian dari tugas yang diberikan kewenangan oleh peraturan perundang-undangan kepada kepolisian sebagaimana yang ditegaskan dalam pasal 15 ayat (1) huruf c dalam undang-undang nomor 2 tahun 2002 tentang kepolisian Negara republic Indonesia

\footnotetext{
${ }^{8}$ Irwansyah, Kanit Res Aceh Timur, wawancara, 20 April 2021.

${ }^{9}$ Agus Satria, Penyidik Polsek Idi Rayeuk, wawancara, 20 April 2021.

${ }^{10}$ Agus Satria, Penyidik Polsek Idi Rayeuk, wawancara, 20 April 2021.

${ }^{11}$ Irwansyah, Kanit Res Aceh Timur, wawancara, 20 April 2021.

12 Syahrul, Polres Aceh Timur, wawancara 21 April 2021

${ }^{13}$ Agus Satria, Penyidik Polsek Idi Rayeuk, wawancara, 20 April 2021.

${ }^{14}$ Irwansyah, Kanit Res Aceh Timur, wawancara, 20 April 2021.
} 
yaitu kepolisan berwenang mencagah dan menanggulangi tumbuhnya penyakit masyaakat. Salah satu perbuatan yang dianggap sebagai penyakit sosial dalam kehidupan bermasyarakat adalah penyalahgunaan obat dan narkotika. ${ }^{15}$

Kepolisian Aceh Timur telah melakukan beberapa upaya dalam pelaksanaan tugasnya di bidang penegakan hukum di Wilayah yurisdiksinya yang berkaitan dengan penanggulangan kejahatan narkotika. Upaya yang telah dilakukan baik yang besifat preventif atau pencegahan maupun represif. Kedua model upaya ini terus dilakukan agar narkotika baik sabu-sabu maupun ganja dapat hilang di wilayah Aceh Timur.

Pelaksanaan tugas Preventif yang dilakukan oleh kepolisian di wilayah hukum Aceh Timur dapat dikategorikan menjadi dua kelompok besar, yaitu:

1. Pencegahan yang bersifat fisik dengan melakukan empat tugas utama, yaitu mengatur, menjaga, mengawal dan patroli.

2. Pencegahan yang bersifat pembinaan dengan melakukan kegiatan penyuluhan, bimbingan, arahan, sambang, anjang sana untuk mewujudkan masyarakat yang sadar dan taat hukum serta memiliki daya cegah-tangkal atas kejahatan.

Peran yang dilakukan oleh kepolisian sebagai wujud pelaksanaan wewenang yang diberikan kepadanya adalah razia kendaraan bermotor setiap saat apabila dipandang diperlukan. Langkah ini merupakan upaya preventif yang dilakukan agar dapat mencegah peredaran narkotika melalui jalur darat. ${ }^{16}$ Langkah ini dianggap efektif dalam mengungkapkan berbagai macam modus yang dilakukan oleh pelaku penyalahgunaan narkotika di Aceh Timur. Razia akan dilakukan Ketika adanya laporan dari masyarakat terkait dengan peredaran narkotika sehingga mencegah penyebarluasanya dengan mengadakan Razia sehingga dapat menghindari transaksi jual beli narkotika di kalangan masyarakat.

Langkah preventif selanjutnya yang dilakukan oleh kepolisian resort Aceh Timur adalah dengan cara mengadakan tes urine pada internal kepolisian untuk menjaga asumsi bahwa tidak ada yang kebal dengan hukum.

Adapun upaya preventif yang diberikan oleh Kepolisian, BNNP dan masyarakat di wilayah yurisdiksi Aceh Timur adalah sebagai berikut:

1. Mensosialisasi Bahaya Narkotika bagi Masyarakat dan Anak-Anak

Sosialiasasi merupakan usaha untuk memberikan informasi kepada masyarakat dan anak-anak dengan memberikan pemahaman tentang jenis-jenis narkotika yang tidak boleh dikonsumsi, langkah-langkah yang harus dilakukan agar terhindar dari narkotika, bahaya yang dihadapi oleh pengguna narkotika bagi diri dan masa depannya serta hukuman atau sanksi yang akan diberikan bila seseorang menggunakan narkotika serta menyebarluaskan atau memperjualbelikan narkotika kepada pengguna lainnya. Sosialisasi yang telah dilakukan oleh aparat kepolisian dan BNNP adalah dengan cara turun ke sekolah-sekolah. ${ }^{17} \mathrm{Hal}$ ini dilakukan agar anak-anak yang masih sekolah tidak terpengaruh oleh narkotika. Biasanya bagi anak-anak di usia remaja ini sangat rawan

\footnotetext{
${ }^{15}$ Irwansyah, Kanit Res Aceh Timur, wawancara, 20 April 2021.

${ }^{16}$ Agus Satria, Penyidik Polsek Idi Rayeuk, wawancara, 20 April 2021.

${ }^{17}$ Fazlon, Anggota BNN, wawancara, 22 April 2021.
} 
dengan mengkonsumsi narkotika yang disebabkan oleh karena pemikiran yang belum matang, tidak berfikir lebih jauh terhadap masa depannya serta dampak-dampak yang muncul dari penyalahgunaan narkotika.

Menurut Rudi, orangtua menjadi elemen yang sangat penting dalam upaya mencegah dan menanggulangi praktik narkotika di Aceh Timur. ${ }^{18}$ Orangtua adalah orang yang selalu mengamati dan mengawasi terkait perilaku anaknya. Komitmen orangtua untuk menjaga dan mencegah penyalahgunaan narkotika sangat mungkin dilakukan agar menghindari hal-hal yang membahayakan bagi dirinya. Hal yang harus dilakukan oleh orangtua adalah selalu memantau kehidupan dan pergaulan anaknya. Orangtua juga perlu menyampaikan bahaya narkotika kepada anak sebagai bentuk edukasi penting bagi dirinya. Nasehat orangtua kemungkinan akan menjadi pertimbangan bagi anak untuk tidak melanjutkan penyalahgunaan narkotika.

Kebanyakan masyarakat menyampaikan bahwa sanksi memiliki pengaruh yang sangat kuat bagi anak-anak. Kebanyakan dari mereka lebih takut kepada sanksi yang diatur dalam peraturan perundang-undangan dibandingkan dengan rusaknya tubuh bagi mereka akibat dari penyalahgunaan narkotika. Hal ini menunjukkan bahwa tingkat kesadaran hukum dari masyarakat sangatlah rendah. Secara umum ada tiga alasan yang mendorong seseorang mentaati hukum sebagaimana yang diungkapkan oleh, yaitu: pertama, Ketaatan hukum masyarakat bersifat compliance, artinya seseorang akan mentaati sebuah produk hukum dikarenakan dalam ketentuan hukum yang diatur dalam ketentuan peraturan perundang-undangan disertai dengan sanksi bagi masyarakat yang tidak menjalankannya. Oleh karenanya, UU Narkotika memberikan hukuman yang berat bagi pelaku kejahatan narkotika sebagaimana yang termaktub dalam Pasal 114 ayat (1) Setiap orang yang tanpa hak atau melawan hukum menawarkan untuk dijual, menjual, membeli, menerima, menjadi perantara dalam jual beli, menukar, atau menyerahkan Narkotika Golongan I, dipidana dengan pidana penjara seumur hidup atau pidana penjara paling singkat 5 (lima) tahun dan paling lama 20 (dua puluh) tahun dan pidana denda paling sedikit Rp1.000.000.000,00 (satu miliar rupiah) dan paling banyak Rp10.000.000.000,00 (sepuluh miliar rupiah). Sanksi tersebut menjadi dasar untuk memberikan dampak secara psikologis bagi masyarakat untuk memikirkan kembali dalam melakukan atau tidaknya kejahatan narkotika.

Ketaatan hukum dengan sifat compliance dikarenakan mentaati suatu aturan karena adanya ketakutan kepada penegak hukum, memiliki kini memiliki kelemahankelemahan, karena masyarakat yang taat hukum dengan sifat ini harus diawasi secara terus menerus. ${ }^{19}$ Bila tidak diawasi akan melakukannya. Fenomena yang sering berkembang di wilayah Aceh Timur ini sesuai dengan sifat yang pertama karena menaati hukum yang telah diatur dalam UU Narkotika karena di dalamnya diancam dengan sanksi bagi masyarakat yang tidak melaksanakannya. Oleh karenanya,

\footnotetext{
${ }^{18}$ Rudi, Anggota BNN, wawancara, 22 April 2021

${ }^{19}$ Achmad Ali, Menguak Teori Hukum (Legal Theory) dan Teori Peradilan (Judicial Prudence) Termasuk Interprestasi Undang-undang (legisprudence), Kencana, Jakarta, 2009, hal. 352.
} 
pengawasan secara terus menerus harus diupayakan, baik pengawasan yang dilakukan oleh kepolisian, BNNP maupun masyarakat itu sendiri.

Kedua, ketaatan hukum masyarakat bersifat identification, yaitu ketaatan hukum seseorang dikarenakan adanya iming-iming sesuatu yang lain. Bila tidak mentaati hukum akan menyebabkan hubungan baiknya menjadi tidak harmonis. Ketaatan hukum yang seperti ini yang dipraktikkan oleh masyarakat juga mengalami kelemahan, karena ketaatan hukum bukan atas dasar keinginan dan kesadaran dari dirinya sendiri. Ketiga, Ketaatan yang bersifat internalization, yaiutu jika seseorang menaati suatu aturan, benar-benar karena merasa bahwa aturan itu sesuai dengan nilainila intristik yang dianutnya. ${ }^{20}$

2. Menyebarkan Bahan Media Campaign

Langkah kedua yang dilakukan oleh kepolisian dan BNNP adalah dengan menyebarkan bahan material Kampanye kepada masyarakat sampai semua lapisan. Baik yang berkedudukan di kota maupun yang berada di wilayah pesisir dan pegunungan. Bahan media campaign yang disebarkan dalam bentuk yang bervariasi yaitu spanduk, baliho dan poster yang berisikan pesan untuk menghindar dari perbuatan penyalahgunaan narkotika. Menurut Muhammad Ali, yang merupakan Tuha Peut Gampong Titi Baro, upaya ini telah memberikan andil yang cukup untuk mengurangi penyalahgunaan narkotika di gampong. ${ }^{21}$ Apalagi pada pesan tersebut di samping tulisannya melarang juga disertai dengan foto-foto yang mengerikan sehingga masyarakat dan anak-anak akan semakin menggunakan narkotika. Hal yang sama juga diungkapkan oleh Keuchik Gampong Ulee Glee Idi Timur, Syamsuar, bahwa penyebaran media campaign ini pada prinsipnya juga bisa menjadi salah satu strategi yang paling ampuh bisa mengurangi praktik narkotika dan peraderannya di wilayah Aceh Timur. Usaha tersebut perlu dilanjutkan agar benar-benar bisa diminimalisir kejahatan di bidang narkotika. Selain itu, kepolisian Aceh Timur telah melakukan sosialisasi secara intensif kepada anak-anak terkait bahaya narkotika di wilayah Aceh. Sosialisasi diberikan untuk mengantisipasi agar anak-anak tidak terjerumus ke dalam perbuatan penyalahgunaan narkotika. ${ }^{22}$

3. Penyampaian Melalui Kegiatan Keagamaan

Sebagai salah satu pihak yang berperan penting dalam upaya menanggulangi narkotika di tingkat gampong adalah aparatur desa, dalam hal ini terdiri dari keuchik, tuha peut dan imeum meunasah. Keberadaannya juga turut berkontribusi dalam pencegahan narkotika di Aceh Timur. Langkah yang sering dilakukan oleh aparatur gampong adalah dengan cara memberikan nasehat melalui khutbah jumat atau ceramah pada hari besar Islam. Langkah ini juga memiliki pengaruh yang signifikan bagi masyarakat setempat. Apalagi dalam kesempatan itu tidak hanyak dihadiri oleh orangtua, anak muda turut berhadir untuk melaksanakan sholat secara berjamaah.

\footnotetext{
${ }^{20}$ Achmad Ali, Menguak Teori Hukum (Legal Theory) dan Teori Peradilan (Judicial Prudence) Termasuk Interprestasi Undang-undang (legisprudence), Kencana, Jakarta, 2009, hal. 352.

${ }^{21}$ Muhammad Ali, Tuha Peut Gampong Titi Baro, 22 April 2021.

${ }^{22}$ Agus Satria, Penyidik Polsek Idi Rayeuk, wawancara, 20 April 2021.
} 
Menurut Kanitres Aceh Timur, hampir setiap gampong ada di adakan pengajian baik ditingkat gampong maupun kecamatan dan hal tersebut dilakukan secara rutin dan berkesinambungan guna pengkajian hal-hal yang bersifat duania maupun akhirat. ${ }^{23} \mathrm{Hal}$ yang juga diungkapkan oleh Keuchik Gampong Blang Geulumpang, Iskandar, yang mengatakan penangkanlan kejahatan yang merupakan penyakit yang muncul di masyarakat dilakukan dengan memberikan siraman rohani melalui pengajian yang diadakan sescara rutin di setiap meunasah dan masjid. ${ }^{24}$ Hal ini sangat penting sekali dilakukan agar dapat menyadarkan masyarakat serta menghindari dari perbuatanperbuatan yang diharamkan oleh agama dan negara. Begitu pula sebagaimana yang disampaikan oleh imeum gampong Blang Geulumpang, Tgk. Mahmuddin yang menerangkan bahwa ceramah agama dengan penggunaan teks-teks Al-Quran senantiasa menjadi pengingat bagi masyarakat dan anak muda agar terhindar dari perbuatan dosa. ${ }^{25}$

4. Pengawasan Berkelanjutan

Pengawasan merupakan salah satu cara yang paling efektif untuk mencegah peredaran narkotika. Tindakan ini sering dilakukan oleh aparatur gampong agar masyarakat tidak terjerumus pada perbuatan yang dilarang oleh agama dan negara. Pengawasan dilakukan oleh aparatur gampong pada malam hari dengan melaksanakan patroli di tempat-tempat yang dianggap mencurigakan. Selain aparatur gampong, dari pihak kepolisian dan BNNP terkadang sering melakukan pengawasan di daerah Aceh Timur.

5. Membuat MoU terkait Komitmen Pemberatasan Narkotika

Adapaun kebijakan konkrit para pihak dalam penangana penyalahgunaan narkotika di Aceh Timur adalah dengan membuat MOU antar para pihak dengan komitmen berantas narkotikan tanpa pandang bulu dengan pola penegakan hukum terhadap para pelakunya.

Penyalahgunaan narkoba terjadi disebabkan oleh banyak faktor, secara umum ada beberapa faktor yang menyebabkan terjadinya sebuah kejahatan. Pertama adalah faktor yang berasal atau terdapat dalam diri si pelaku yang maksudnya bahwa yang mempengaruhi seseorang untuk melakukan sebuah kejahatan itu timbul dari dalam diri si pelaku itu sendiri yang didasari oleh faktor keturunan dan kejiwaan (penyakit jiwa). Faktor yang kedua adalah faktor yang berasal atau terdapat di luar diri pribadi si pelaku. Maksudnya adalah: bahwa yang mempengaruhi seseorang untuk melakukan sebuah kejahatan itu timbul dari luar diri si pelaku itu sendiri yang didasari oleh faktor rumah tangga dan lingkungan. ${ }^{26}$ Menurut Kanit Reskrim Aceh Timur, ada beberapa alasan yang menjadi faktor dominan yang cenderung terjadi di Aceh Timur, yaitu: pertama, pergaulan/sosial. ${ }^{27}$ Pergaulan di era modern seringkali mengarah kepada hal-hal yang

\footnotetext{
${ }^{23}$ Irwansyah, Kanit Res Aceh Timur, wawancara, 20 April 2021.

${ }^{24}$ Iskandar, Keuchik Gampong Blang Geulumpang Idi Rayeuk, 14 April 2021.

${ }^{25}$ Mahmuddin, Imeuem Gampong Blang Geulumpang Idi Rayeuk, 14 April 2021.

${ }^{26}$ Andi Hamzah, Hukum Pidana dan Acara Pidana, (Jakarta: Ghalia Indonesia.1986), hlm. 64

${ }^{27}$ Irwansyah, Kanit Res Aceh Timur, wawancara, 20 April 2021.
} 
tidak baik bila tanpa adanya control dan pengendalian dari diri sendiri. Masyarakat yang tidak membatasi dirinya dari pergaulan cenderung dapat dipengaruhi dengan pola kehidupan yang menjurus kepada perbuatan-perbuatan yang dilarang oleh agama dan negara. Menurut Tuha Peuet Gampong Titi Baro $^{28}$, pengaruh sosial dan lingkungan dalam sebuah komunitas sangat menentukan perilaku yang akan lahir dalam komunitas tersebut. Kalau perilakunya baik, dapat dipastikan kehidupan dalam komunitas tersebut akan menjadi baik pula. Sebaliknya, bila sikap dalam berinteraksi yang dipertontonkan masyarakat tidak baik akan berimplikasi kepada hal-hal yang tidak baik pula. ${ }^{29} \mathrm{Kedua}$, ekonomi, dikarenakan asumsi masyarakat adalah nilai ekonomis yang tinggi. Ketiga, peredaran yang cukup tinggi sehingga mudah diketemukan karena dipasarkan secara luas oleh oknum-oknum yang tidak bertanggungjawab. ${ }^{30}$

Faktor terjadinya penyalahgunaan narkotika di Aceh Timur yaitu: Letak geografis. Karena letak daerahnya yang dekat dengan selat malaka dan juga berdekatan dengan provinsi Sumatera Utara. Selain itu, wilayah Aceh Timur ditemukan tambak yang jauh dari gampong sehingga sulit dideteksi oleh masyarakat ketika konsumsi narkotika dilangsungkan. ${ }^{31}$ Menurut masyarakat gampong Titi Baro, adanya tambak yang jauh dari gampong memiliki potensi untuk digunakan sebagai sarana untuk mengkonsumsi narkotika. Warga yang berada di gampong belum mampu mengontrol serta melakukan pengawasan secara terus menerus. Lagi pula, penyalahgunaan narkotika dilakukan pada malam hari. ${ }^{32}$ Kedua, karena faktor Pendidikan, karena masih ditemukan tingkatan Pendidikan yang rendah di kalangan masyarakat. Banyaknya masyarakat yang tidak memiliki pemahaman secara komprehensif tentang narkotika sehingga mengkonsumsikannya tanpa adanya rasa bersalah. Ketiga, karena tingkat pengangguran tinggi, akibatnya para pemuda tidak mengetahui harus melakukan aktivitas yang produktif. ${ }^{33}$ Akibatnya adalah mengkonsumsikan narkotika sebagai perbuatan untuk mengisi waktu luangnya. Keempat, faktor ekonomi, tingkat ekonomi yang rendah berpengaruh pada perbuatan dan tindakan yang dilakukan oleh masyarakat setempat. ${ }^{34}$ Lemahnya ekonomi masyarakat menjadikan transaksi narkotika sebagai salah satu usaha yang dapat menguntungkan. Pekerjaan tidak terlalu banyak menghabiskan tenaga namun menghasilkan keuntungan yang besar sehingga masyarakat menjadi lebih tertarik menjadikan narkotika sebagai objek yang mendatangkan keutungan. ${ }^{35}$

Pencegahan tidak dianggap sebagai tanggungjawab bersama merupakan bentuk pembiaran terhadap kejahatan narkotika. Kondisi ini sangat berbahaya karena tidak

\footnotetext{
${ }^{28}$ Muhammad Ali, Tuha Peut Gampong Titi Baro, 22 April 2021.

${ }^{29}$ Iskandar, Keuchik Gampong Blang Geulumpang Idi Rayeuk, 14 April 2021.

${ }^{30}$ Irwansyah, Kanit Res Aceh Timur, wawancara, 20 April 2021.

${ }^{31}$ Mahmuddin, Imeuem Gampong Blang Geulumpang Idi Rayeuk, 14 April 2021

${ }^{32}$ Abdullah, Tuha Peut Gampong Blang Geulumpang, 14 April 2021

33 Iskandar, Keuchik Gampong Blang Geulumpang Idi Rayeuk, 14 April 2021.

${ }^{34}$ Muhammad Ali, Tuha Peut Gampong Titi Baro, 22 April 2021

${ }^{35}$ Mahmuddin, Imeuem Gampong Blang Geulumpang Idi Rayeuk, 14 April 2021.
} 
akan mampu menyelesaikan persoalan narkotika sampai ke akar-akarnya kalua hanya dianggap sebagai tanggungjawab dari apparat penegak hukum dan aparatur gampong. Padahal pemberantasan penyalahgunaan narkotika menjadi tanggungjawab bersama baik penegak hukum maupun bagi masyarakat biasa.

Kehadiran Qanun di tingkat gampong menjadi salah satu konkrit yang dapat ditawarkan agar pengawasan praktik penyalahgunaan narkotika menjadi tugas dan tanggungjawab Bersama yang harus dilakukan oleh semua warga gampong. Akan teptai hal ini belum ada satu gampong pun di aceh timur memiliki kesadaran membentuk qanun atau reusam gampong yang mengatur pengawasan dan tanggungjawab Bersama dalam upaya menanggulangi praktik penyalahgunaan narkotika.

Selain fungsi pencegahan, dalam upaya menanggulangi penyalahgunaan narkotika di Aceh Timur juga memerluk penindakan dari apparat penegak hukum dan masyarakat setempat. Penindakan merupakan upaya penindakan dan penegakan hukum terhadap ancaman faktual dengan sanksi yang tegas dan konsisten sesuai dengan Undang-Undang yang berlaku untuk membuat efek jera bagi para pengguna dan pengedar psikotropika. Bentuk-bentuk kegiatan yang dilakukan Polri dalam upaya Represif tersebut adalah:

a. Melaksanakan Fungsi Criminal Justice Sistem

Salah satu fungsi penindakan yang dilakukan oleh kepolisian dan BNNP adalah dengan menjalankan fungsi pelaksanaan system peradilan pidana (Criminal Justice Sistem). Sistem peradilan pidana didefinisikan sebagai sistem dalam masyarakat untuk menanggulangi masalah-masalah kejahatan. Pengertian menanggulangi di sini diartikan sebagai usaha untuk mengendalikan kejahatan agar berada dalam batas-batas toleransi masyarakat ${ }^{36}$. M. Ali Zaidan menyimpulkan tiga tujuan dari sistem peradilan pidana, yaitu ${ }^{37}$ :

a. Mencegah masyarakat menjadi korban kejahatan

b. Menyelesaikan kasus kejahatan yang terjadi sehingga masyarakat puas, bahwa keadilan telah ditegakkan dan yang bersalah dipidana, dan

c. Mengusahakan agar mereka yang pernah melakukan kejahatan tidak mengulangi lagi kejahatannya.

Sistem peradilan pidana dan penjatuhan pidana sebagai bentuk penyelesaian konflik bukan untuk membalas. Pidana dan pemidanaan adalah bentuk pertanggungjawaban pelanggar terhadap akibat (dampak) perbuatan melanggar hukum pidana dan orang yang dirugikan secara langsung akibat kejahatan (korban) bersifat aktif untuk menyelesaikan konflik. Perlindungan hukum terhadap korban selama ini

\footnotetext{
${ }^{36}$ Muhammad Ali Zaidan, Menuju Pembaharuan Hukum Pidana, Jakarta: Sinar Grafika, 2015, hlm. 114

${ }^{37}$ Ibid., hlm. 114.
} 
didasarkan pada KUHP sebagai hukum materiil, dengan menggunakan KUHAP sebagai hukum acara ${ }^{38}$.

Peran yang telah dilakukan oleh kepolisian dalam mengungkapkan praktik penyalahgunaan narkotika di wilayah hukum Aceh Timur adalah sebagai berikut ${ }^{39}$ :

b. Memutuskan peredaran gelap narkotika, psikotropika, dan bahan berbahaya lainnya di wilayah yurisdiksi Aceh Timur dengan berbagai usaha dan Tindakan yang berorientasi kepada pengurangan tingkat penayalahgunakan narkotika di Aceh Timur.

c. Mengungkapkan ke permukaan jaringan sindikat pengedar narkotika dengan mengetahui aktor utamanya yang berperan penyebarluasan narkotika di wilayah hukum Aceh Timur.

d. Melaksanakan Operasi Rutin dan Operasi Khusus terpusat secara kontinyu. Fungsi yang dikedepankan adalah fungsi Reserse.

Tindakan represif/penegakan hukum dimaksudkan untuk dapat mengungkap dan memutus jaringan sindikat perdagangan dan peredaran gelap narkoba baik sekala nasional maupun internasional, melakukan proses penanganan perkara sejak penyidikan sampai lembaga pemasyarakatan secara konsisten dan sungguh-sungguh, mengungkap motivasi/latar belakang dari kejahatan penyalahgunaan dan peredaran gelap narkoba, pemusnahan barang bukti narkoba yang berhasil disita serta pelaksanaan pengawasan dan pengendalian terhadap ketersediaan dan peredaran prekursor serta penyitaan terhadap aset milik pelaku kejahatan perdagangan dan peredaran gelap narkoba. Menurut Heru Permana, penegakan hukum pidana dilakukan dengan beberapa tahapan yaitu, tahapan formulasi, tahap aplikasi dan tahap eksekusi. ${ }^{40}$ 2 Koordinasi antara Kepolisian, Badan Narkotika Nasional Provinsi dan Masyarakat dalam Menanggulangi Praktik Penyalahgunaan Narkotika

Koordinasi yang telah dibangun inten selama ini hanya antara masyarakat dengan kepolisian. Sementara koordinasi dengan pihak BNNP masih sangat terbatas dilaksanakana oleh masyarakat. ${ }^{41} \mathrm{Hal}$ ini dikarenakan oleh beberapa alasan yang sering dihadapi oleh masyarakat, yaitu: Pertama, BNNP tidak ditugaskan di wilayah yurisdiksi Aceh Timur untuk melakukan patroli secara terus menerus. Kendala ini memiliki pengaruh yang kuat dalam mengungkapkan informasi. BNNP yang sebenarnya menjadi elemen penting dalam kaitannya penanggulangan kejahatan narkotika justru tidak disediakan di Aceh Timur. Sebagai lembaga penegak hukum di bidang narkotika, BNNP disediakan oleh pemerintah karena lembaga penegak hukum menjadi komponen berhasil atau tidaknya dilaksanakan sebuah aturan hukum. Menurut Soerjono Soekanto, suatu aturan hukum dapat berjalan efektif disebabkan oleh beberapa alasan yaitu karena struktur of law (penegak hukum), substantial of law

${ }^{38}$ Siswanto Sunarso, Victimologi dalam Sistem Peradilan Pidana, cet. 1, Jakarta: Sinar Grafika, 2012, hl. 72.

${ }^{39}$ Syahrul, Polres Aceh Timur, wawancara 21 April 2021.

${ }^{40}$ Heru Permana, Politik Kriminal, (Yogyakarta: Universitas Atmajaya, 2007), hlm. 60.

${ }^{41}$ Irwansyah, Kanit Res Aceh Timur, wawancara, 20 April 2021. 
(aturan hukum), culture of law (budaya hukum masyarakat) dan sarana prasarana yang mendukung pelaksanaan suatu aturan hukum. ${ }^{42}$ Penegak hukum memiliki peran yang sangat signifikan dalam penegakan hukum. Hukum dapat dipastikan tidak berjalan dengan baik apabila pada tataran empiris tidak dilengkapi dengan apparat penegak hukumnya dalam hal ini adalah BNNP yang diberikan kewenangan untuk melaksanakan segala aktivitas di bidang penegakan hukum narkotika. Hingga saat ini belum ada BNN di Aceh Timur sehingga kepolisian di wilayah Aceh Timur mengalami kesulitan dengan berkoordinasi dengan pihak BNN. Penegak hukum merupakan salah satu faktor yang mendukung efektif atau tidaknya penegakan hukum dalam sebuah komunitas masyarakat.

Mekanisme koordinasi yang dilakukan selama ini oleh Kepolisian, BNNP dan masyarakat dalam melaksanakan narkotika adalah sebagai berikut:

Pertama, menghubungi kepolisian. Masyarakat yang berdomisili di gampong menjadi pilar yang tak dapat diabaikan dalam proses penegakan UU Narkotika. Kedudukannya di gampong akan sangat membantu kepolisian dan BNN dalam melacak dan memetakan daerah-daerah yang dianggap rawan terhadap praktik penyalahgunaan dan peredaran narkotika. Hal ini dikarenakan kedudukannya di gampong sehingga sangat mudah mendeteksi orang-orang yang melakukan peredaran narkotika. Masyarakat gampong yang telah memiliki tingkat kesadaran yang tinggi akan menghubungi atau berkoordinasi dengan pihak kepolisian bilamana menurut observasi yang dilakukan adanya hal-hal yang mencurigakan dan mengarah kepada penyalahgunaan narkotika. Masyarakat gampong lebih dominan berkoodinasi dengan pihak kepolisian dibandingkan dengan BNNP. Jarak antara masyarakat dengan BNNP menjadi salah satu alasan yang seringkali disampaikan oleh masyarakat sehingga tidak dapat melaporkan praktik tersebut kepada BNNP. BNNP tidak ada yang ditugaskan di wilayah Aceh Timur sehingga masyarakat lebih memilih melaporkan peristiwa tersebut kepada kepolisian yang ada di wilayahnya.

Persoalan yang seringkali dihadapi di lapangan oleh kepolisian adalah tidak semua masyarakat memiliki kesadaran terhadap pelaporan kasus penyalahgunaan narkotika di Aceh Timur. Hanya sebagian kecil masyarakat yang telah mulai sadar terkait dengan pelaporan peristiwa tersebut kepada pejabat yang berwenang. Menurut Kanit Resort Kriminal Aceh Timur, kurangnya simpati masyarakat terhadap apparat penegak hukum menjadi persoalan yang dapat menghambat dalam pengungkapan kasus narkotika. ${ }^{43}$ Dampak yang muncul adalah kurangnya kasus-kasus yang terungkap ke permukaan, karena tidaknya keterlibatan aktif masyarakat serta tidaknya adanya sinergisitas yang baik antara masyarakat dengan kepolisian dan BNN. ${ }^{44} \mathrm{Hal}$ ini menunjukkan suatu persoalan tersendiri yang ada di gampong yang perlu dilakukan strategi yang tepat agar masyarakat melaporkan setiap tindak pidana narkotika kepada kepolisian agar dapat diproses sesuai dengan ketentuan peraturan perundang-undangan

\footnotetext{
${ }^{42}$ Soerjono Soekanto, Loc. Cit, hlm. 42.

43 Irwansyah, Kanit Res Aceh Timur, wawancara, 20 April 2021.

${ }^{44}$ Rudi, Anggota BNN, wawancara, 22 April 2021.
} 
yang berlaku. Masyarakat cenderung mendiamkan terhadap peristiwa tersebut padahal sudah mengetahui dampak terhadap diri dan masa depan pelakunya. Kesadaran melaporkan ini dilatarbelakangi oleh beberapa sebab yaitu karena yang mengkonsumsinya memiliki hubungan persaudaraan dengannya serta menjadi aib bagi keluarga bila adanya kerabat dan saudaranya yang terkena kasus narkotika. ${ }^{45} \mathrm{Hal}$ ini menjadi salah satu sebab yang menyebabkan pelaksanaan aturan menjadi tidak efektif yang dilatarbelakangi oleh karena budaya hukum masyarakat yang tidak melakukan pelaporan terhadap kejahatan yang ada di tempatnya masing-masing. Menurut Satjipto Rahardjo, pelaksanaan hukum itu sangat ditentukan dan dipengarui oleh sikap, pandangan dan nilai yang dihayatinya, oleh karenanya melihat dilaksanakan atatu tidaknya suatu aturan hukum sangat bergantung pada perilaku dari masyarakt yang bersangkutan. ${ }^{46}$ Untuk itulah, budaya hukum masyarakat yang senantiasa melaporkan setiap tindak pidana yang terjadi di daerahnya akan menjadi sebuah fakta bahwa penegakan aturan tentang narkotika dapat terlaksana dengan baik pula dalam kenyataan empiris.

Orang tua merasa malu kalau ada anaknya ditangkap dengan kasus penyalahgunaan narkotika. Akibatnya, orang tua tidak melaporkan perbuatan dari anaknya kepada pihak yang berwajib disebabkan kekhawatiran adanya rasa malu diketahui perbuatan buruk oleh warga sekitar dan perangkat desa. ${ }^{47}$ Kecenderungan ini berakibat tidak baik dalam mengungkapkan serta membasmi sampai ke-akar-akarnya penyalahgunaan dan peredaran narkotika. Menurut BNN, pihak kepolisian dan BNNP mengalami kesulitan mengakses informasi disebabkan ketidakterbukaan dari masyarakat itu sendiri. Masyarakat tidak menyampaikan keberadaan praktik penyalahgunaan ini disebabkan oleh beberapa faktor sebagai berikut: pertama, Menganggap bahwa bila melaporkan kepada pihak yang berwajib, maka secara tidak langsung telah membuka aib keluarga, karena yang melakukan penyalahgunaan narkotika berasal dari keluarganya. Kedua, Adanya anggapan bahwa ketika diproses melalui system peradilan pidana berujung kepada penghukuman dengan penjatuhan pidana penjara dalam jumlah yang lama. ${ }^{48}$ Ketiga, harus mengikuti mekanisme sistem peradilan yang panjang dengan pihak kepolisian dan BNNP karena kecenderungan dari aparat penegak hukum menggunakan criminal justice system untuk memproses seseorang yang dididuga melakukan kejahatan narkotika. Proses tersebut sangat Panjang, sejak di tingkat kepolisian untuk dilakukan penyeledidikan dan penyidikan untuk menunjukkan ada atau tidaknya perbuatan pidana berdasar alat bukti yang cukup. Kemudian bila dianggap telah adanya bukti yang cukup, persoalan tersebut dilimpahkan kepada pihak Kejaksaan untuk dilakukan dakwaan dan penuntutan kepada pengadilan di wilayah yurisdiksinya masing-masing. Pada tahap pengadilan akan diputuskan bersalah atau tidaknya seseorang yang diduga melakukan penyalahgunaan

45 Iskandar, Keuchik Gampong Blang Geulumpang Idi Rayeuk, 14 April 2021.

${ }^{46}$ Satjipto Rahardjo, Hukum dan Masyarakat, Angkasa Bandung, 1980, hal.85.

${ }^{47}$ Mahmuddin, Imeuem Gampong Blang Geulumpang Idi Rayeuk, 14 April 2021.

${ }^{48}$ Rudi, Anggota BNN, wawancara, 22 April 2021. 
narkotika sehingga mendapatkan putusan terhadap perbuatan tersebut. Keempat, Menghabiskan biaya yang banyak untuk melakukan pendampingan dengan menggunakan jasa advokat untuk memberikan pembelaan terhadap anaknya.

Anggapan masyarakat yang menganggap bahwa konsekuensi dari penyalahgunaan narkotika berakhir dengan narkotika sebenanya kurang tepat dari sistem hukum yang berlaku di Indonesia khususnya yang berkaitan dengan narkotika. UU Narkotika disamping memberikan hukuman penjara juga memberikan hukuman berupa rehabilitasi kepada orang yang melakukan penyalahgunaan narkotika. Baik yang bersifat rehabilitasi sosial maupun rehabiltasi medis. Rehabilitasi Medis adalah suatu proses kegiatan pengobatan secara terpadu untuk membebaskan pecandu dari ketergantungan Narkotika. ${ }^{49}$ Rehabilitasi Sosial adalah suatu proses kegiatan pemulihan secara terpadu, baik fisik, mental maupun sosial, agar bekas pecandu Narkotika dapat kembali melaksanakan fungsi sosial dalam kehidupan masyarakat. ${ }^{50}$ Rehabilitasi sosial bagi para pecandu narkoba juga dapat diartikan sebagai bentuk atau proses pemantapan sosial bagi para pecandu narkoba yang meliputi segala upaya yang bertujuan memupuk, memelihara, membimbing, dan meningkatkan rasa kesadaran dan tanggung jawab sosial bagi pribadinya, keluarga dan masyarakat. ${ }^{51}$ Berkaitan dengan hukuman ini diatur secara tegas dalam Pasal 127 Ayat (2) mewajibkan kepada hakim untuk memperhatikan Pasal 54, 55 dan Pasal 103 dalam memutuskan kasus narkotika. Pasal 54 UU tersebut mengatur bahwa Pecandu Narkotika dan korban penyalahgunaan Narkotikawajib menjalani rehabilitasi medis dan rehabilitasi sosial.

UU Narkotika memberikan ruang partisipasi yang seluas-luasnya kepada masyarakat untuk turut berkontribusi dan memberikan informasi kepada pihak yang berwenang terkait dengan narkotka. Pasal 104 UU Narkotika menyatakan bahwa Masyarakat mempunyai kesempatan yang seluas-luasnya untuk berperan serta membantu pencegahan dan pemberantasan penyalahgunaan dan peredaran gelap narkotika dan Prekursor Narkotika. Ketentuan ini memberikan tiga kewenangan kepada masyarakat yaitu mencegah, memberantas dan menghambat penyebarluasan narkotika. Secara yuridis keikutsertaan masyarakat diakui dan harus dilaksanakan sebagaimana mestinya. Partisipasi masyarakat merupakan sebagai bentuk tanggungawab masyarakat sebagaimana yang diamanatkan oleh Pasal 105 UU Narkotika yang menyatakan bahwa masyarakat mempunyai hak dan tanggung jawab dalam upaya pencegahan dan pemberantasan penyalahgunaan dan peredaran gelap Narkotika dan Prekursor Narkotika.

Kedua, Kepolisian menghubungi atau berkoordinasi dengan BNNP. Setelah informasi diterima oleh kepolisian, Langkah selanjutnya adalah melakukan koordinasi dengan BNNP untuk dilakukan penindakan secara Bersama-sama baik berupa

\footnotetext{
${ }^{49}$ Pasal 1 angka 16, Undang-undang Nomor 35 tahun 2009 tentang Narkotika.

${ }^{50}$ Pasal 1 angka 17, Undang-undang Nomor 35 tahun 2009 tentang Narkotika.

51 Sumarno Masum, Penanggulangan Bahaya Narkotika dan Ketergantungan Obat, Jakarta; CV. Haji Masagung, 1987, hlm. 139
} 
penyelidikan maupun penyidikan terhadap suatu kejahatan yang diduga penyalahgunaan narkotika. ${ }^{52}$

Ketiga, BNNP yang akan melakukan tugas di bidang penyelidikan dan penyidikan untuk mendapatkan bukti-bukti yang cukup sehingga perkara tersebut dapat diduga sebagai sebuah tindak pidana.

Sistematika koordinasi dapat diliihat pada skema berikut ini:

\section{Masyarakat}

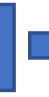

Kepolisian
BNNP

Koordinasi yang dihadapi di lapangan selama ini masih banyak mengalami kendala dalam pelaksanaannya, yaitu: Pertama, ego sektoral. Problematika yang sering ditemukan di lapangan dalam upaya penanggulangan kejahatan narkotika adalah adanya ego sectoral di masing-masing lembaga. ${ }^{53}$ Ego ini dapat menimbulkan konflik tersendiri antar Lembaga sehingga menyebabkan penegakan hukum menjadi terhambat. Kedua, Jarak antara Kepolisian dengan BNNP. Hal ini dikarenakan BNNP tidak ada di Aceh Timur, akibatnya Kepolisian Aceh Timur melakukan koordinasi dengan BNNP yang berkedudukan di Provinsi. ${ }^{54}$ Ketiga, terbatasnya SDM BNNP. Artinya dengan jumlah SDM BNNP yang sangat terbatas belaum memadai atau mengakomodir dengan jumlah kasus narkotika yang secara terus menerus meningkat tajam. Akibatnya adalah tidak ada keseimbangan antara jumlah kasus dengan jumlah personel yang tersedia. Keempat, Jumlah kasus yang ditangani oleh BNNP sangat tinggi. Jumlah kasus yang ada sangat tinggi sehingga membutuhkan kehati-hatian dalam mengungkapkannya. Selain itu, di samping penegakan hukum, BNNP juga bertugas memberikan rehabilitasi kepada pecandu narkotika agar tidak mengulangi perbuatannya. $^{55}$

Salah satu yang mempengaruhi penegakan hukum dalam kenyataan sosiologis adalah keterbatasan sarana dan prasarana yang disediakan oleh pemerintah. Sarana yang mendukung dalam mengungkapkan kasus narkotika memiliki peran yang sangat membantu kepolisian dan BNNP untuk menemukan dan mendeteksi keberadaan narkotika serta peredarannya di Aceh. Akan tetapi, sarana dan prasarana itu tidak tersedia di Aceh Timur. Akibatnya adalah sangat sulit bagi kepolisian mendeteksi dan mengidentifikasi peredaran gelap narkotika. Sarana yang dibutuhkan tapi tidak tersedia di Aceh Timur yang mendukung atau sebagai penunjang pelaksanaan tugas di bidang penegakan UU Narkotika adalah pelacak nomor telpon aktif dengan sistem GPS, pembaca sim card (simcard reading), alat pendeteksi Narkoba canggih yakni detector canggih ( $x$-ray, scanning, dan lain sebagainya), detector kendaraan roda empat maupun roda dua. ${ }^{56}$ Berbagai fasilitas yang seyogyanya dibutuhkan tapi belum disediakan oleh

\footnotetext{
52 Syahrul, Polres Aceh Timur, wawancara 21 April 2021

${ }^{53}$ Rudi, Anggota BNN, wawancara, 22 April 2021.

${ }^{54}$ Syahrul, Polres Aceh Timur, wawancara 21 April 2021.

55 Fazlon, Anggota BNN, wawancara, 22 April 2021.

${ }^{56}$ Irwansyah, Kanit Res Aceh Timur, wawancara, 20 April 2021.
} 
pemerintah yang mendukung kepolisian dalam mengungkapkan kasu penyalahgunaan narkotika. Keterbatasan sarana dan prasana menurut Soerjono Soekanto juga merupakan salah satu yang dapat menentukan efektif atau tidaknya suatu aturan hukum dalam kenyataan konkrit di lapangan. ${ }^{57}$ Sarana dan prasana yang dibutuhkan antara satu instansi dengan instansi yang lain sangat berbeda sesuai dengan kebutuhan dan tugas pokoknya masing-masing.

Keberadaan berbagai macam alat pendeteksi ini sangat dibutuhkan karena perkembangan model peredaran narkotika seiring berkembangnya peradaban manusia yang begitu pesat. Pola transaksi yang terjadi dewasa ini menggunakan media elektronik untuk mengkomunikasikan keberadaan narkotika. ${ }^{58}$ Akibat belum adanya alat yang dapat mendeteksi komunikasi antara pembeli dan penjual narkotika sehingga pemberantasan narkotika tidak mampu dicegah sampai ke akar-akarnya. Kepolisian dan BNN mengalami kesulitan untuk melakukan pendeteksi ini ada atau tidaknya transaksi narkotika. Kesulitan ini juga dialami oleh masyarakat dalam mengungkapkan narkotika, karena proses transaksi melalui elektronik. ${ }^{59}$

\section{D.Kesimpulan}

Berdasarkan berbagai permasalahan yang telah peneliti uraikan dalam penelitian ini, mka dapat disimpulkan bahwa Kepolisian, Badan Narkotika Nasional Provinsi dan masyarakat memiliki peranan yang sangat stategis serta berkontribusi penting dalam penanggulanangan kejahatan di Aceh Timur. Ketiga institusi telah menunjukkan tanggungjawabnya secara kelembagaan dalam upaya mencegah dan menunggapkan praktik penyalahgunaan narkotika meskipun hasil yang diharapkan masih belum begitu maksimalPeran koordinatif dilakukan dengan cara berkoordinasi baik secara langsung maupun tidak langsung kepada lembaga yang berwenang. Koordinasi antara Kepolisian, Badan Narkotika Nasional Provinsi dan masyarakat merupakan instrument yang tepat dalam upaya mengurangi praktik penyalahgunaan narkotika. Hal ini disebabkan oleh karena masyarakat kedudukan di gampong yang menyaksikan secara langsung praktik kejahatan narkotika. Koordinasi antara masyarakat dengan kepolisian dan BNNP masih belum berjalan secara maksimal. Hal ini dikarenakan kedudukan BNNP hanya di tingkat Provinsi, sementara di Aceh Timur belum ada lembaga tersebut. Konsekuensinya praktik kejahatan penyalahgunaan narkotika tidak dapat terungkap sampai ke akar-akarnya. Kerjasama antar berbagai sektor sangat dibutuhkan agar segala bentuk kejahatan di bidang narkotika, baik yang mengedarkan maupun penyahgunaan dapat terungkap sebaik-baiknya ke permukaan. Bila langkah ini tidak dilakukan akan mengakibatkan meningkatnya angka penyalahgunaan narkotika di Aceh Timur.

\section{b.Rekomendasi}

\footnotetext{
${ }^{57}$ Soerjono Soekanto, Sosiologi Hukum, Jakarta: Grafika, 2006, hlm. 45.

${ }^{58}$ Irwansyah, Kanit Res Aceh Timur, wawancara, 20 April 2021.

${ }^{59}$ Irwansyah, Kanit Res Aceh Timur, wawancara, 20 April 2021.
} 
Disarankan kepada pemerintah pusat agar dapat membentuk unit BNN khusus di Kabupaten Aceh Timur agar dapat bersinergi dengan kepolisian dalam mengungkapkan kasus penyalahgunaan narkotika sampai ke akar-akarnya di wilayah hukum Aceh Timur. Disarankan kepada POLRI, BNN dan masyarakat yang merupakan ujung tombak dalam mengungkapkan kejahatan narkotika untuk terus bersinergi dan berkoordinasi dalam memberikan informasi terkait penyalahgunaan narkotika.

\section{Daftar Pustaka}

\section{A. Buku}

Achmad Ali, 2009. Menguak Teori Hukum (Legal Theory) dan Teori Peradilan (Judicial Prudence) Termasuk Interprestasi Undang-undang (legisprudence), Kencana, Jakarta.

Andi Hamzah, 1986, Hukum Pidana dan Acara Pidana, Jakarta: Ghalia Indonesia.

Muhammad Ali Zaidan, 2015 Menuju Pembaharuan Hukum Pidana,: Sinar Grafika. Jakarta

Sumarno Masum, 1987 Penanggulangan Bahaya Narkotika dan Ketergantungan Obat, CV. Haji Masagung, Jakarta.

Heru Permana, 2007 Politik Kriminal, Universitas Atmajaya, Yogyakarta:

Satjipto Rahardjo, 1980 Hukum dan Masyarakat, Angkasa Bandung.

Siswanto Sunarso, 2012 Victimologi dalam Sistem Peradilan Pidana, cet. 1: Sinar

Grafika, Jakarta

B. Jurnal

Bayu Puji Hariyanto, Pencegahan dan Pemberantasan Peredaran Narkoba Di Indonesia, Jurnal Daulat Hukum, vol. 1, no. 1, 2018.

Fransiska Novita Eleanora, Bahaya Penyalahgunaan Narkoba Serta Usaha Pencegahan Dan Penanggulangannya (Suatu Tinjauan Teoritis), Jurnal Hukum, Vol XXV, No. 1, April 2011.

Gunawan Antiprawiro,"Peran Masyarakat Dalam Pencegahan Dan Penanggulangan Terhadap Penyalahgunaan Dan Peredaran Gelap Narkotika", Sociae Polites, vol. 15, No. 2, 2014.

\section{Peraturan Perundang-undangan}

Undang-Undang Nomor 2 Tahun 2002 tentang Kepolisian Negara Republik Indonesia Undang-Undang Nomor 35 Tahun 2009 tentang Narkotika

Peraturan Presiden Republik Indonesia Nomor 23 Tahun 2010 tentang Badan Narkotika Nasional

Qanun Aceh Nomor 9 Tahun 2008 tentang Pembinaan Kehidupan Adat Istiadat

Qanun Aceh Nomor 10 Tahun 2008 tentang Lembaga Adat Aceh.

\section{Internet/Media Online}


https://aceh.tribunnews.com/2020/04/17/polres-aceh-timur-amankan-sabu-sekitar-45-kg-termasuklima-tersangka-nelayan, diakses pada hari Senin, 19 Mei 2020.

https://www.ajnn.net/news/bnn-tangkap-bandar-narkoba-di-aceh-timur-18-kg-sabu-disita/index.html, diakses pada hari Senin 19 Mei 2020.

https://aceh.antaranews.com/berita/119321/polisi-ciduk-tiga-pria-penyalahgunaan-narkotika-di-acehtimur, diakses pada hari Senin 19 Mei 2020. 